\title{
PENGARUH SIKAP, NORMA SUBJEKTIF, DAN KONTROL PERILAKU TERHADAP MINAT BELI
}

\author{
F. Purwantini ${ }^{1}$, L. E. Tripalupi ${ }^{2}$ \\ 1,2 Jurusan Ekonomi dan Akuntansi, Universitas Pendidikan Ganesha, Singaraja \\ E-mail : fitriapurwantini@gmail.com, tripalupilulup@gmail.com
}

\begin{abstract}
Abstrak
Tujuan dari penelitian ini untuk mengetahui pengaruh-pengaruh sikap, norma subjektif, dan kontrol perilaku terhadap minat beli. Penelitian kausal merupakan penelitian yang diguanakan dalam penelitian ini. Penelitian ini dilaksanakan di Universitas Pendidikan Ganesha (UNDIKSHA) dengan sampel berjumlah 390 responden. Penelitian ini menggunakan jenis data kuantitatif hasil dari kuesioner, sedangkan sumber data mengunakan data primer. Dalam penelitian ini metode angket adalah metode yang digunakan untuk pengumpulan data. Instrument penelitian yang digunakan yaitu kuesioner dengan skala likert. Teknik atau cara menganalisis data yang digunakan yaitu analisis regresi linier berganda, uji t, dan uji f dengan aplikasi olah data SPSS. Penelitian ini menunjukan hasil bahwa terdapat pengaruh secara parsial dan simultan sikap, norma subjektif, dan kontrol perilaku terhadap minat beli kosmetik konsumen.
\end{abstract}

Kata kunci: sikap, norma subjektif, kontrol perilaku, minat beli

\begin{abstract}
The purpose of this study to determine the effects of attitudes, subjective norms, and behavioral control on purchase intention. Causal research is the research used in this study. This research was conducted at the Ganesha Education University (UNDIKSHA) with a sample of 390 respondents. This study uses quantitative data from questionnaires, while the data source uses primary data. In this study, the questionnaire method is a method used for data collection. The research instrument used was a questionnaire with a Likert scale. Techniques or ways to analyze the data used are multiple linear regression analysis, $t$ test, and $f$ test with the SPSS data processing application. This study shows the results that there is a partial and simultaneous influence on attitudes, subjective norms, and behavioral control on consumer buying interest in cosmetics.
\end{abstract}

Keywords : Attitude, behavior control, buying interest, subjective norm

\section{Pendahuluan}

Kosmetik merupakan kebutuhan setiap orang, baik laki - laki maupun perempuan. Mereka menggunaan kosmetik untuk riasan wajah, perawatan dan pengharum tubuh. Permintaan akan kosmetik saat ini membuat kosmetik menjadi sangat beragam sesuai dengan kebutuhan setiap konsumen. Di pasaran banyak jenis kosmetik yang ditawarkan mulai dari beragam kemasan, merek, harga, dan kualitas. Hal ini membuat minat konsumen dalam memilih dan membeli kosmetik jadi sangat beragam. Slameto (dalam tripalupi \& Irwansyah, 2018) minat adalah rasa ketertarikan pada sesuatu yang berasal dari dalam diri.

Menurut theory of planned behavior yang mempengaruhi minat perilaku ada tiga konstruk yaitu attitude, subjective norm, and behavior control. Teori perlilaku rencanaan merupakan perluasan dari teori tindakan beralasam menurut Fishbein dan Ajzen (dalamJogiyanto, 2007). Teori tindakan beralasan adalah konsep perilaku manusia yang paling utama untuk mempengaruhi minat berperilaku dari seseorang. Teori tersebut sudah digunakan diberbagai bidang sepeerti, pemasaran, system informasi dan bidang lainnya. Pada konsep ini ada variabel-variabel penentu perilaku yakni, sikap periiaku dan norma subjektif. Selanjutnya Icek Ajzen mengembangkan teori tindakan beralasan ini menjadi konsep perilaku rencanaan Jogiyanto, (2007). Theory of planed behavior mengembangkan theory of resoned action atas tambahan konstruk yaitu kontrol perilaku persepsi yang yang sebelumnya tidak terdapat pada TRA yang dimana kontrol perilaku persepsian ini dipersepsikan akan mempengaruhi minat dan perilaku.

Melalui hasil penelitian awal yang sudah dilakukan terhadap minat konsumen dalam membeli kosmetik, bahwa ada berbagai alasan yang mendorong minat konsumen dalam membeli kosmetik di antaranya harga, pendapat dari teman, kenyamanan produk saat digunakan, dan juga rasa percaya diri saat menggunakan produk tersebut. Menurut riset yang 
dilakukan oleh Cahya Tri Rachmantika dengan 100 responden mengungkapkan bahwa yang mempengaruhi minat beli adalah variabl-variabel yang terdapat dalam penelitian ini.

Berdasarkan apa yang telah dipaparkan di atas minat konsumen dalam membeli kosmetik merupakan isu yang menarik untuk diteliti dengan alasan seperti yang di atas karena banyaknya kosmetik yang beredar di pasaran yang menyebabkan minat konsumen dalam membeli kosmetik juga ikut beragam. Theory of planed behavior selanjutnya dijadikan salah satu acuan untuk menentukan pengaruh pada riset ini. Dari latar belakang tersebut penulis mengambil judul " Pengaruh Sikap, Norma Subjektif dan Kontrol Perilaku Terhadap Minat Konsumen dalam Membeli kosmetik".

\section{Metode}

penelitian kausal dengan karakteristik masalah hubungan sebab akibat antara dua variabel atau bahkan lebih adalah Jenis penelitian yang digunakakn dalam penelitian ini (Sugiyono, 2013). Terdapat tiga variabel bebas dan satu variabel terikat. Penelitian ini dilaksanakan di Universitas Pendidikan Ganesha (UNDIKSHA). Universitas Pendidikan Ganesha merupakan satu-satunya Universitas Negeri di kabupaten Buleleng sehingga memiliki beragam (majemuk) mahasiswa yang datang darii bermacam-macam golongan di Bali ataupun luar Bali dengan karakteristik yang bermacam-macam.

Seluruh mahasiswa Universitas Pendidikan Ganesha jenjang D3 dan S1 dengan jumlah mahasiswa sebanyak 10.833 merupakan populasi yang digunakan dalam penelitian ini dengan rincian fakultas bahasa dan seni sebanyak 1877 mahasiswa, fakultas ekonomi sebanyak 2959 mahasiswa, fakultas hukum dan ilmu sosial sebanyak 517 mahasiswa, fakultas ilmu pendidikan sebanyak 1923 mahasiswa, fakultas kedokteran sebanyak 98, fakultas mipa sebanyak 1326 mahasiswa, FOK sebanyak 736 mahasiswa, FTK sebanyak 1397 mahasiswa,

Banyaknya populasi tidak memungkinkan peneliti untuk mengambil semua, maka untuk menyederhanakan jumlah sampel dari sebuah populasi digunakanlah perhitungan slovin .

Keterangan :

$$
\mathrm{n}=\frac{N}{1+N e^{2}}
$$

$\mathrm{n}:$ Sampel

$\mathrm{N}$ : Populasi

$e:$ Taraf kesalahan atau nilai kritis

Tingkat keakuratan yang digunakan pada pengambilan sampel ini sebesar $95 \%$ atau linai kritis 5\%, maka ukuran sampel dihitung dengan cara berikut:

$$
\begin{aligned}
& \mathrm{n}=\frac{N}{1+N e^{2}} \\
& \mathrm{n}=\frac{10.833}{1+10.833(5 \%)^{2}}
\end{aligned}
$$

$$
\mathrm{n}=385,75
$$

Berdasarkan perhitungan di atas maka didapatkan sampel sebanyak 385,75 dibulatkan menjadi 386 sampel. Teknik sampling yang diguanakan dalam penelitian ini adalah secara kebetulan, yaitu siapapun yang secara tak sengaja ditemui dapat digunakan sebagai sampel jika dipandang cocok sebagai responden (Sugiyono,2009).

Penyebaran sampel pada tiap-tiap fakultas dapat digunakan perhitungan sebagai berikut. 


$$
\text { Ukuran sampel }=\frac{\text { jumlah populasi }}{\text { populasi }} \times \text { sampel }
$$

Penyebaran sampel nampak pada table 1.

Table 1. Sebaran Sampel

\begin{tabular}{lccc}
\hline \multicolumn{1}{c}{ Fakultas } & Populasi & Perhitungan & $\begin{array}{c}\text { Pembagian } \\
\text { sampel } \\
\text { (dibulatkan) }\end{array}$ \\
\hline $\begin{array}{l}\text { Fakultas bahasa dan } \\
\text { seni }\end{array}$ & 1877 & $\frac{1877}{10833} \times 386=66,8$ & 67 \\
Eakultas ekonomi & 2959 & $\frac{2959}{10833} \times 386=105,4$ & 106 \\
$\begin{array}{l}\text { Fakultas hukum dan } \\
\text { ilmu social }\end{array}$ & 517 & $\frac{517}{10833} \times 386=18,4$ & 19 \\
$\begin{array}{l}\text { Fakultas ilmu } \\
\text { pendidikan }\end{array}$ & 1923 & $\frac{1923}{10833} \times 386=68,5$ & 69 \\
$\begin{array}{l}\text { Fakultas kedokteran } \\
\text { Fakultas mipa }\end{array}$ & 98 & $\frac{98}{10833} \times 386=3,4$ & 4 \\
Fakultas olabraga dan & 1326 & $\frac{1326}{10833} \times 386=47,2$ & 48 \\
kesebhatan & 736 & $\frac{736}{10833} \times 386=26,2$ & 27 \\
$\begin{array}{l}\text { Fakultas teknik dan } \\
\text { kejuruan }\end{array}$ & 1397 & $\frac{1397}{10833} \times 386=49,7$ & 50 \\
\hline
\end{tabular}

Menurut Sugiyono (2017) pada perhitungan yang menghasilkan pecahan sebaiknya dibulatkan ke atas sehingga jumlah sampelnya melebihi jumlah 386.

Data kuantitatif digunakan dalam penelitian ini dengan sumber data yaitu data primer yang didapat melaluii hasil penyebaran kuisioner. Metode angket adalah cara yang diguanakan untuk mengumpulkan data berupa pertanyaan-pertanyaan. Cara ini disebut juga dengan kuesioner atau daftar pertanyaan. Metode angket adalah sekumpulan daftar pertanyaan yang susunannya sistematis, lalu diisi oleh responden. Pengujian instrument penelitian ini yaitu uji validitas dan reliabilitas. Alat yang digunakan adalah Uji validitas untuk memperhitungkan layak dan taklayak kuesioner untuk disebarkan terhadap seseorang. Untuk menguji valditas digunakan analisis korelasi product moment. Uji reliabilitas adalah alat yang berfungsi sebagai alat keajegan dari suatu kuesioner. Uji statistic Cronbach's Alpha $>0,6$ adalah teknik untuk menguji uji reliabilitas.

Metode analisis datanya yaitu analisis regresi linier berganda karena menggunakan tiga variabel bebas dan satu variabel terikat. Analisis regresi linier berganda dirumuskan dalam persamaan berikut :

$$
Y=a+\beta 1 X 1+\beta 2 X 2+\beta 3 X 3+\varepsilon
$$

Keterangan:

$\mathrm{Y}=$ Minat beli konsumen

$\mathrm{a}=$ Konstanta 
$\beta=$ Koefisien regresi

$\varepsilon=$ Error term

$\mathrm{X}_{1}=$ Sikap

$\mathrm{X}_{2}=$ Norma subjektif

$\mathrm{X}_{3}=$ Kontrol perilaku

Layak tidaknya menggunakan analisis linier berganda mula-mula melakukan uji normalitas, multikolonerialitas, serta heteroskedastisitas sebagai uji awal. Uji normalitas merupakan teknik yang guna mengetahui apakah data sudah terdistribusi norma atau tidak. Data sudah terdistribusi normal hasilnya bisa dicek pada uji one sample kolmogornov-smirnov.

Uji multikoloniertitas digunakan untuk menemukan adanya hubungan antar variabel bebas disuatu penelitian. Bentuk regresi yang tepat sebaiknya tak ada hubungan antar variabel independennya. Variabel yang saling berhubungan artinya variabel bebas yang tidak memiliki nilai sama dengan nol.

Uji heteroskedastisitas digunakan untuk menetahui penyimpangan-penyimpangan yang mungkin terdapat pada uji model regresi. Tidak terjadi homoskedastisitas atau tidak terjadi heteroskedastisitas adalah model regresi yang baik. Uji hesteroskedastisitas pada penelitian ini adalah menggunakan metode glejser. Uji t untuk melihat apakah variabel berpengaruh secara parsial atau tidak maka dapat di lihat pada tabel hasil analisis yang sudah dilakukan dengan aplikasi olahdata. secara parsial digunakan uji simultan (Uji F).

\section{Hasil dan Pembahasan}

\section{Pengaruh Sikap Terhadap Minat Beli}

Berdasarkan hasil analisis data sebagai berikut.

Tabel 2. Uji t Pengaruh Sikap Terbadap Minat Beli

\begin{tabular}{|c|c|c|c|c|c|c|}
\hline \multirow[b]{3}{*}{ Model } & & \multicolumn{3}{|c|}{ Coefficients ${ }^{a}$} & \multirow[b]{3}{*}{$t$} & \multirow{4}{*}{$\begin{array}{l}\text { Sig. } \\
0,000\end{array}$} \\
\hline & & \multicolumn{2}{|c|}{$\begin{array}{l}\text { Unstandardized } \\
\text { Coefficients }\end{array}$} & \multirow{2}{*}{$\begin{array}{c}\begin{array}{c}\text { Standardized } \\
\text { Coefficients }\end{array} \\
\text { Beta }\end{array}$} & & \\
\hline & & $\mathrm{B}$ & Std. Error & & & \\
\hline 1 & (Constant) & 5,561 & 0,548 & & 10,152 & \\
\hline & SIKAP & 0,704 & 0,034 & 0,721 & 20,476 & 0,000 \\
\hline
\end{tabular}

Sumber Output SPSS versi 25.0 for Windows

Berdasarkan tabel di atas ditunjukan hasil niali t sebesar 20,476. Dapat dilihat Sig. 0,000 $<0,050$. Artinya terdapat pengaruh.

Pengaruh Norma Subjektif Terhadap Minat beli

Berdasarkan hasil analisis data sebagai berikut.

Tabell 3. Uji t Pengaruh Norma Subjektif Terbadan Minat Beli

\begin{tabular}{|c|c|c|c|c|c|}
\hline & & efficient: & & & \\
\hline & $\begin{array}{r}\text { Unsta } \\
\text { Cos }\end{array}$ & $\begin{array}{l}\text { zed } \\
\text { ts }\end{array}$ & $\begin{array}{l}\text { Standardized } \\
\text { Coefficients }\end{array}$ & & \\
\hline Model & $\mathrm{B}$ & $\begin{array}{l}\text { Std. } \\
\text { Error }\end{array}$ & Beta & $\mathrm{t}$ & Sig. \\
\hline 1 (Constant) & 11,611 & 0,485 & & 23,923 & 0,000 \\
\hline $\begin{array}{l}\text { NORMA } \\
\text { SUBJEKTIF }\end{array}$ & 0,352 & 0,033 & 0,475 & 10,629 & 0,000 \\
\hline
\end{tabular}

a. Dependent Variable: MINAT BELI

Sumber Output SPSS versi 25.0 for Windows 
Berdasarkan tabel di ditunjukan hasil niali t sebesar 10,629 dapat dilihat Sig. 0,000<0,050. Hal ini berarti terdapat pengaruh

\section{Pengaruh Kontrol Perilaku Terhadap Minat Beli}

Berdasarkan hasil analisis data sebagai berikut.

Tabel 4 . Uji t Pengaruh Kontrol Perilaku Terhadap Minat Beli

\begin{tabular}{|c|c|c|c|c|c|}
\hline & & efficient & & & \\
\hline & $\begin{array}{r}\text { Unstandar } \\
\text { Coefficie }\end{array}$ & $\begin{array}{l}\text { zed } \\
\text { ts }\end{array}$ & $\begin{array}{l}\text { Standardized } \\
\text { Coefficients }\end{array}$ & & \\
\hline Model & B & $\begin{array}{l}\text { Std. } \\
\text { Error }\end{array}$ & Beta & $\mathrm{t}$ & Sig. \\
\hline $\begin{array}{ll}1 & \text { (Constant) }\end{array}$ & 7,664 & 0,395 & & 19,400 & 0,000 \\
\hline $\begin{array}{l}\text { KONTROL } \\
\text { PERILAKU }\end{array}$ & 0,586 & 0,025 & 0,762 & 23,204 & 0,000 \\
\hline
\end{tabular}

a. Dependent Variable: MINAT BELI

Sumber Output SPSS versi 25.0 for Windows

Berdasarkan tabel di atas ditunjukan hasil niali t sebesar 23,204 dapat dilihat Sig. 0,000< 0,050. Hal ini berarti terdapat pengaruh.

\section{Pengaruh Sikap, Norma Subjektif, dan Kontrol Perilaku Terhadap Minat Beli}

Berdasarkan hasil analisis data sebagai berikut.

Tabel 5. Uji f Pengaruh Sikap, Norma Subjektif, dan Kontrol Perilaku Terbadap Minat Beli

\begin{tabular}{|c|c|c|c|c|c|c|}
\hline \multicolumn{7}{|c|}{ ANOVAa } \\
\hline \multicolumn{2}{|c|}{ Model } & \multirow{2}{*}{$\frac{\text { Sum of Squares }}{1742,200}$} & \multirow{2}{*}{$\frac{\mathrm{df}}{3}$} & \multirow{2}{*}{$\begin{array}{r}\text { Mean Square } \\
580,733\end{array}$} & \multirow{2}{*}{$\frac{F}{337,408}$} & \multirow{2}{*}{$\frac{\text { Sig. }}{.000^{\mathrm{b}}}$} \\
\hline 1 & Regression & & & & & \\
\hline & Residual & 664,367 & 386 & 1,721 & & \\
\hline & Total & 2406,567 & 389 & & & \\
\hline
\end{tabular}

a. Dependent Variable: MINAT BELI

b. Predictors: (Constant), KONTROL PERILAKU, NORMA SUBJEKTIF, SIKAP

Berdasarkan table di ditunjukan hasil niali f sebesar 337,408 dapat dilihat Sig. 0,00<0,050. Hal ini berarti terdapat pengaruh .

Nilai Adjusted $R$ Square pada penelitian ini dapat di lihat pada table berikut.

Table 6. Koefisien Determinasi

\section{Model Summary}

\begin{tabular}{|c|c|c|c|c|}
\hline & & R Square & $\begin{array}{l}\text { Adjusted R } \\
\text { Square }\end{array}$ & Std. Error of the Estimate \\
\hline 1 & $.851^{\mathrm{a}}$ & 0,724 & 0,722 & 1,312 \\
\hline
\end{tabular}

Sumber Output SPSS versi 25.0 for Windows

Hasil tabel menunjukkan, diperoleh hasil besarnya pengaruh sebesar 0,722. Artinya variabel independen mempengaruhi variabel dependent sebesar $72,2 \%$, dan sisanya sebesar $27,8 \%$ diterangkan variabel lain. 
Untuk mencari persamaan garis regresi digunakan analisis koefisien Beta. Hasil analisis tersebut menunjukkan hasil yang tertera pada table berikut .

Table 7. Perhitungan Koefisien Beta

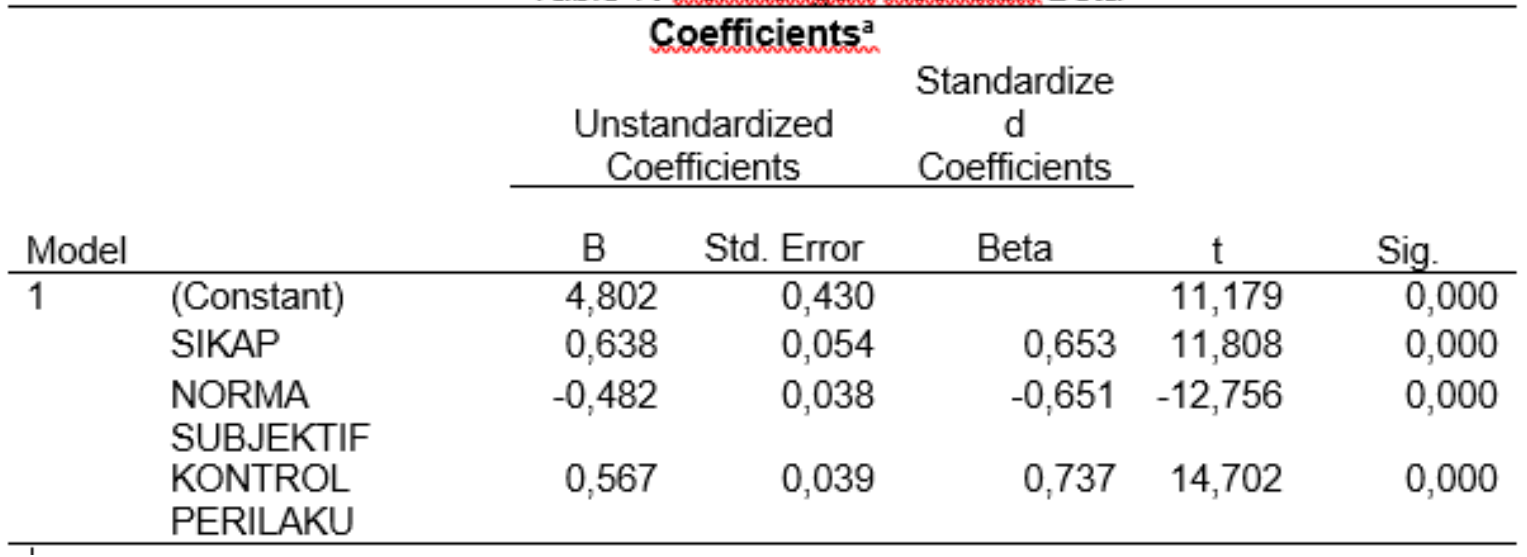

a. Dependent Variable: MINAT BELI

Sumber Output SPSS versi 25.0 for Windows,.

Berdasarkan table di atas menunjukkan bahwa, hasil persamaan garis regresi sebagai berikut

$$
\begin{aligned}
& Y=a+\beta 1 X 1+\beta 2 X 2+\beta 3 X 3+\varepsilon \\
& Y=4,802+0,638 X 1-0,482 X 2+0,567 X 3
\end{aligned}
$$

Diketahui hasil konstanta adalah sebesar 4,802 artinya variabel independent bernilai konstan atau nol, variabel dependen memiliki nilai positif sebesar 4,802. Variabel sikap (X1) memiliki koefisien positif sebesar 0,638 , variabel norma subjektif (X2) memiliki koefisien negatif sebesar $-0,482$ dan variabel kontrol perilaku (X3) memiliki nilai 0,567 . Nilai koefisien yang bernilai positif menunjukan bahwa X1 dan X2 berpengaruh positif terhadap minat beli. Sedangkan koefisien yang bernilai negatif menunjukan bahwa variabel $\mathrm{X} 3$ berpengaruh negatife terhadap $\mathrm{Y}$.

\section{Pengaruh Sikap Terhadap Minat Beli}

Hasil analisis data menunjukan bahwa ada pengaruh. Pendapat Fishbein dan Ajzen (dalam (Jogiyanto, 2007) mengatakan dalam model minat berperilaku (theory of reasoned action), yang paling mempengaruhi minat ada dua yaitu sikap dan norma subjektif. Riset ini sesuai dengan riset oleh Binalay. Mandey. Mintardjo. (2016) yaitu terdapat positif sikap dengan minat beli konsumen secara online berdasarkan hasil analisis uji hipotesis. Hal ini dilihat dari nilai signifikansi yang lebih kecil dari $5 \%$ atau 0,05 . Penelitian lain yang dilakukan oleh Lenggu (2016) juga menunjukkan pengaruh positif dan signifikan dalam penelitiannya yaitu membeli ulang di centro department store Yogyakarta..

\section{Pengaruh Norma Subjektif Terhadap Minat Beli}

Hasil analisis data menunjukan bahwa ada pengaruh antara norma subjektif terhadap minat konsumen dalam membeli kosmetik. Hal ini didukung oleh pendapat dari London dan Della (dalam Albari \& Liriswati, 2004) menyatakan bahwa minat konsumen bukan hanya dilihat dari sikap semata melainkan juga norma subjektif yang mempertimbangkan persepsi orang lain apabila melakukan perbuatan tertentu. Pendapat lainnya yang dikemukakan oleh Fishbein dan Ajzen (dalam Jogiyanto, 2007) yang mengatakan selain sikap, minat dan perilaku ada peentu diluar itu yang bisat mempengaruhi minat berperilaku seseorang yaitu norma subjektif. Penelitian yang dilakukan oleh Ediyanto (2016) menyatakan hasil variabel norma subjektif pengaruh positisf dengan minat. 


\section{Pengaruh Kontrol Perilaku terhadap Minat Beli}

Hasil analisis data menunjukan bahwa ada. Hasil ini didukung oleh pendapat dari Ajzen (dalam Dharmmesta, 1998) yang mengatakan bahwa kontrol perilaku dapat mempengaruhi minat dari seseorang. Hasil penelitian oleh Yohana (2011) menunjukan adanya pengaruh yang positif dan signifikan antara kontrol perilaku terhadap minat beli konsumen. Penelitian lain yang dilakukan oleh Witriyana, Faisal, dan Rifani, (2019) menunjukkan hasil yang sama.

\section{Pengaruh Sikap, Norma Subjektif, dan Kontrol Perilaku Terhadap Minat Beli}

Hasil analisis data menunjukan bahwa ada. Besarnya nilai variabel-variabel independen dengan variabel dependen ditunjukan pada table 5 , dimana dapat dilihat besarnya pengaruh sebesar 0,722 atau $72,2 \%$. Menurut pendapat dari Jogiyanto (2007) tiga variabel ini secara akan mempengaruhi minat berperilaku seseorang yaitu, variabel sikap, norma subjektif, dan kontrol perilaku. Penelitian yang dilakukan oleh Rachmantika (2018) menunjukan hasil bahwa variabel tersebut diatas secara simultan mempengaruhi minat beli kosmetik.

\section{Simpulan dan Saran}

Berdasarkan hasil analisis data yang diproses menggunakan aplikasi SPSS dan pembahasan yang telah diuraikan pada bab sebelumnya, maka dapat ditarik kesimpulan secara parsial variabel sikap berpengaruh terhadap minat beli, variabel norma subjektif berpengaruh terhadap minat beli, dan variabel kontrol perilaku berpengaruh terhadap minat beli. Secara simultan variabel sikap, norma subjektif, dan kontrol perilaku berpengaruh terhadap minat beli.

Berdasarkan hasil simpulan penelitian maka yang dapat peneliti sarankan yaitu, Bagi pemilik usaha, diharapkan untuk membuat inovasi-inovasi guna menumbuhkan minat beli konsumen misal membuat promosi dengan memberikan potongan harga. Bagi peneliti selanjutnya disarankan hendaknya menggunakan objek penelitian yang lebih spesifik misalkan pada fakultas atau jurusan tata kecantikan sehingga benar-benar bisa mewakili keadaan yang sebenarnya.

\section{Daftar Pustaka}

Albari, A., \& Liriswati, A. 2004. Analisis Minat Beli Konsumen Sabun Cair Lux, Biore dan Lifebuoy di Kotamadya Yogyakarta Ditinjau dari Pengaruh Sikapnya Setelah Melihat Iklan di Televisi dan Norma Subyektif. Jurnal Siasat Bisnis, Vol.2, No.9, hal.213-239.

Dharmmesta, Basu Swastha. 1998. Theory Of Planned Behaviour Dalam Penelitian Sikap, Niat dan Perilaku Konsumen. Jurnal KELOLA, Vol.7, No.18, hal. 85-103

Ediyanto. 2016. Pengaruh Sikap Dan Norma Subjektif Terhadap Minat Dan Keputusan Mahasiswa Dalam Memilih Perguruan Tinggi Universitas Abdurrachman Saleh Situbondo (UNARS). Jurnal Ekonomi Dan Bisnis GROWTH, Vol.14, No.2, hal.58-71.

Jogiyanto. 2007. sistem informasi keperilakuan. Yogyakarta: C. V Andi Offset

Lenggu, Remalya foti. 2016. Pengaruh sikap dan norma subjektif pada minat membeli ulang di centro depatement store Yogyakarta. skripsi tidak diterbitkan. Yogyakarta: FE Universitas Sanata Dharma

Mintardjo, C. M., Mandey, S., \& Binalay, A. G. 2016. Pengaruh Sikap, Norma Subjektif Dan Motivasi Terhadap Minat Beli Secara Online Pada Mahasiswa Fakultas Ekonomi Dan Bisnis Di Manado. Jurnal Riset Ekonomi, Manajemen, Bisnis Dan Akuntansi, Vo.4,No.1, hal.395-406. 
Rachmantika, C. T. 2018. Sikap, Norma Subjektif, dan Kontrol Perilaku terhadap Minat Beli Kosmetik Halal. Skripsi tidak diterbitkan. FEB islam Institut Agama Islam Negeri Surakarta.

Sugiyono. 2013. Metode Penelitian Kuantitatif, Kualitatif dan R\&D. Bandung: Alfabeta

Taurusia. Yohana, A. 2011. Pengaruh Sikap, Norma Subjektif dan Persepsi Kontrol Perilaku Terhadap Minat Beli Konsumen Melalui Online Shopping. Skripsi tidak diterbitkan. Yogyakarta : FE Universitas Atma Yaya.

Tripalupi, L. endah, \& Irwansyah, M. R. 2018. Pengaruh Personal Attitude, Subjective Norms Danperceived Behavior Control Terhadap Minat Profesi Sekretaris Pada Program Keahlian Administrasi Perkantoran Di Smk Negeri 1 Singaraja Tahun Ajaran 2017/2018. Jurnal Pendidikan Ekonomi, Vol.11, No.2, hal 89-98.

Witriyana, Yuwinda, et. al. 2019. Pengaruh sikap, norma subyektif, kontrol perilaku, terhadap minat beli produk secara online di shopee. Jurnal IImu Manajemen Indonesia, Vol.2, No.1,hal.39-52. 